\title{
Seminal plasma protein profile based on molecular weight and their correlation with semen quality of Simmental bull
}

\author{
A. Baharun ${ }^{1,2}$, R. I. Arifiantini ${ }^{3}$,* N. W.K. Karja ${ }^{3}$ and S. Said ${ }^{4}$ \\ ${ }^{1}$ Biology Reproductive Program, Post Graduate School, IPB University, \\ Jl.. Raya Dramaga, Dramaga Campus, Bogor 16680 -Indonesia \\ ${ }^{2}$ Animals Science Program, Faculty of Agriculture, Djuanda University, \\ Jl. Tol Jagorawi No 1, Ciwawi, Bogor 16720 - Indonesia \\ ${ }^{3}$ Department of Clinic, Reproduction, and Pathology, Faculty of Veterinary Medicine, \\ IPB University, Jl. Agatis Raya, Dramaga Campus, Bogor 16680 - Indonesia \\ ${ }^{4}$ Research Center for Biotechnology, Indonesia Institute of Sciences (LIPI), \\ Jl. Raya Jakarta-Bogor, Cibinong, Bogor 16911 - Indonesia \\ *CorrespondingE-mail: Arifiantini@apps.ipb.ac.id
}

Received August 04, 2020; Accepted November 21, 2020

\begin{abstract}
ABSTRAK
Balai Inseminasi Buatan (BIB) memproduksi semen beku yang berasal dari pejantan unggul. Seleksi pejantan dilakukan berdasarkan breeding soundness examination (BSE). Penelitian ini bertujuan untuk mengevaluasi hubungan antara berat molekul (BM) protein plasma semen dengan kualitas semen pejantan sapi simental. Semen dikoleksi dari sembilan ekor sapi pejantan simental milik Balai Inseminasi Buatan Daerah (BIBD), Jawa Tengah di Ungaran, Semen dikoleksi serta dievaluasi secara makroskopis dan mikroskopis. Semen selanjutnya disentrifugasi (6500 rpm, 30 menit). Supernatan dimasukkan ke dalam straw dan disimpan dalam nitrogen cair. Karakterisasi protein dilakukan menggunakan 1D-SDS-PAGE. Gel diwarnai menggunakan Coomassie Brilliant Blue dan penentuan massa molekul ditentukan berdasarkan penanda BM. Hasil penelitian menunjukkan tidak ada korelasi yang signifikan antara konsentrasi protein dengan kualitas semen $(\mathrm{P}>0.05)$. Ekspresi protein dengan $\mathrm{BM}$ 62-48 kD dan 100-71 kD ditemukan dalam penelitian ini. Hasil analisis korelasi menunjukkan bahwa $\mathrm{BM}$ protein 100-71 kD berkorelasi dengan motilitas sperma, morfologi sperma normal, dan konsentrasi sperma. Semua parameter kualitas semen berhubungan nyata $(\mathrm{P}<0.05$ dan $\mathrm{P}<0.01)$ dengan $\mathrm{BM}$ protein 62-48 kD. Protein plasma semen berkorelasi dengan kualitas semen dan dapat digunakan sebagai indikator tambahan selain BSE dalam seleksi calon sapi pejantan.
\end{abstract}

Kata kunci : protein plasma semen, kualitas semen, sapi pejantan simental

\begin{abstract}
Artificial Insemination Center (AIC) produces frozen semen that was taken from superior bull. The selection of superior bull was based on breeding soundness evaluation. This study is aimed to evaluating the correlation between the molecular weight (MW) of seminal plasma protein and semen quality of Simmental bulls. Semen ejaculates from nine Simmental Bulls, that belong to AIC of Central Java, at Ungaran, were collected by using an artificial vagina. The sub population of sperm in ejaculates was evaluated through macroscopically and microscopically, in which the semen then centrifugated 6500 rpm for 30 minutes. The supernatant was collected and inserted into mini straw and stored in liquid nitrogen container. The concentration of seminal plasma protein was determined by the Bradford
\end{abstract}


method. The Bradford protocol of analysis was suitable with User Guide Coomasize (Bradford) Protein Assay Kit. Thermo Skanlt RE for Multiskan Go Software, 3.2 version was applied for analyzing of the data, and protein characterization used was 1D-SDS-PAGE. The Coomassie Brilliant Blue was used for coloring the gels, and the proteins MW was determined by MW markers. The result demonstrated that there was no significant correlation between protein concentration and semen quality $(\mathrm{P}>0.05)$. Protein expressions based on MW were $62-48 \mathrm{kD}, 100-71 \mathrm{kD}$ found in this study. The analysis of correlation showed that the proteins with 100-71 kD MW correlated with sperm motility, normal sperm morphology, and sperm concentration. Semen quality in all parameters was significant $(\mathrm{P}<0.05$ and $\mathrm{P}>0.01$ ) with $62-48 \mathrm{kD}$ protein MW. The result concluded that seminal plasma protein had a correlation with semen quality and can be used as additional indicator for bull's candidate selection.

Keywords: Seminal plasma protein, semen quality, Simmental bulls

\section{INTRODUCTION}

The bulls in National or Region Artificial Insemination Center were selected superior bulls according to Indonesian Minister of Agricultural Regulation number 10/Permentan/PK.210/3/2016. The normal bulls judged by the body characterization are suitable with their breed, testicles' condition, the normality of internal and external reproduction organs through Breeding Soundness Examination (BSE) method of selection (Hancock et al., 2016). The practical of BSE in Indonesia is well adept such as testicle circumference measurement and health examinations, however, the protocols of semen analysis are only focusing on sperm motility and concentration evaluation. The evaluation of sperm morphology is still not well applied (Arifiantini et al., 2010).

The evaluation systems of bull candidate selection in the world were done by systematic physical examination which focusses on reproductive function, sperm motility, concentration, morphology, and acrosome intact evaluation. This system could be described on sperm fertilities (Chenoweth et al., 2010). Male fertility is sperm ability to fertilize the oocyte. There are many factors in determining the capacity of sperm such as sperm intrinsic factor and seminal plasma components (Viana et al., 2018). There is also potential in exploring the function of protein in which it has correlation with bull's fertility that can be worked by seminal plasma identification (Druart and de Graaf, 2018).

Seminal plasma is a mixed secretion of accessories glands, epididymis, and testis. This secretion contains organic and nonorganic compounds such as fat, ions, metabolite, and proteins (Juyena and Stellete, 2012). The protein in seminal plasma plays an important role in sperm protector regulations (Fu et al., 2019) and also the capacitation of sperm (Jois and Manjunath, 2010). Protein in seminal plasma was processed into acrosome reaction, sperm binding with oocyte process, fertilization and embryo growth initiation (Rodriguez-Villamil et al., 2016). Protein in seminal plasma also protects the sperm during in the male and female reproductive tract (Samanta et al., 2018). Therefore, the proteins study of bull sperm which correlated with bull fertility is necessary to be explored further. This study was aimed to evaluate the correlation between the MW of seminal plasma protein and semen quality of Simmental bulls, and the result of this study can be used as an additional indicator for superior bulls' candidate selection.

\section{MATERIALS AND METHODS}

The experiment was carried out location at Central Java, Artificial Insemination Center (Ungaran, AIC), Unit Rehabilitation Reproduction (URR), Faculty of Veterinary Medicine, IPB University and Dermama Biotechnology Laboratory, Jakarta. The study was carried out with the approval of Animals Ethics Commissions, IPB University from animal used (158-2019 IPB). This study used primary and secondary data of Ungaran, AIC from year 2018 until 2019. Nine selected Simmental bulls were individually caged which were equipped with ration and drink containers. All bulls were fed twice a day with $10 \%$ grass and $1 \%$ concentrate of total body weight and water was given ad libitum.

\section{Semen Collection and Evaluation}

Secondary data of fresh semen quality from Ungaran, AIC was confirmed with direct observation data. The semen was collected by artificial vagina in the morning twice a week. Semen evaluation of macroscopy and microscopy was done immediately after collection. 
Macroscopy evaluations included volume, color, consistency, and acidity $(\mathrm{pH})$ of the semen. Besides that, microscopy evaluation involving mass movement, sperm motility, viability, and morphology was adopted according to Arifiantini (2012)

Sperm motility was evaluated with microscope Olympus CX23, and sperm concentration was calculated using photometer (SDM5, Minitube, Germany). Sperm morphology was also evaluated with calbol-fluchsin eosin stain based on Williams method in 1920 and modified by Lagerlof in 1934 (Kavak et al., 2004).

\section{Determination of Seminal Plasma Protein Concentration and SDS-PAGE}

Semen was centrifugated at $6500 \mathrm{rpm}$ for 30 minutes, and then the supernatant put into the straw and saved in liquid nitrogen (Karunakaran et al., 2019). Protein characterization used 1DSDS-PAGE based on protein MW. The gels stained with Coomassie Brilliant Blue stain and molecular mass were determined by the MW marker (Karunakaran et al., 2019). Concentration of seminal plasma protein was determining by the Bradford method (Bradford, 1976). The Bradford protocol of analysis was suitable with User Guide Coomassie (Bradford) Protein Assay Kit. The data were analyzed by Thermo Skanlt RE for Multiskan Go Software, 3.2 versions.

Protein separation used two polyacrylamide gels $12 \%$ [contain sodium dodecyl sulfate (SDS)]. Protein mass $(20 \mu \mathrm{g})$ was analyzed with SDSPAGE using Thermo Prestained Protein Ladder (5 $\mu \mathrm{L}$, Thermo Scientific $\left.{ }^{\circledR}\right)$ marker. One hundred and twenty (120 volt) voltages in 70 minutes were used for protein separation, and the photo gel color was firstly inverted to and ease for identifying protein bands. Finally, differential intensity from every protein bands was determined by ratio analysis utilizing ImageJ software (Schneider et al., 2012).

\section{Statistical Analysis}

The data of fresh semen quality were analyzed in a descriptive method. Correlation between semen characteristics, protein concentration, and seminal plasma protein was analyzed with Pearson's correlation. Two-way ANOVA (SPSS software 20 version) was applied to the different data groups.

\section{RESULTS AND DISCUSSION}

\section{Fresh Semen Quality and Seminal Plasma} Protein Concentration of Simmental Bulls

The fresh semen quality of 9 Simmental bulls showed that the average semen volume was $6.2 \mathrm{~mL}$. The $\mathrm{pH}$ value was 6.4 with milky-white to creamy in color and medium consistency. Microscopies data showed that sperm motility was $64.37 \%$, sperm concentration $1403.79 \times 10^{6}$ $\mathrm{mL}^{-1}$, normal sperm morphology $94.51 \%$ and sperm with intact acrosome was $92.97 \%$ (Table 1). The fresh semen of Simmental bulls in this study was considered as normal category according to standard of Bos taurus (Parthipan et al., 2017). Based on Indonesian Minister of Agricultural Regulation number: 10/Permentan/PK.210/3/2016 and Indonesian National Standardization 4868.1:2007 for bull frozen semen, the requirements for fresh semen quality which will be processed to be frozen semen should have sperm motility value $>70 \%$ and sperm abnormalities value $<20 \%$. Referring to this regulation, the quality of Simmental bull's fresh semen in this study was considered to be qualified. The normality value was 86.20 to $96 \%$, and sperm motility the Simmental bulls divided into 2 groups; 6 bulls in value $\geq 70 \%$ and 3 bulls $<70 \%$ (Table 1 ).

The seminal protein plasma concentration in this study was $47.28 \mathrm{mg} \mathrm{mL}-1$. The mean of protein plasma concentration in group I (bulls with sperm motility $>70 \%$ ) was $45.66 \mathrm{mg} \mathrm{mL}^{-1}$, and $49.33 \mathrm{mg} \mathrm{mL}^{-1}$ in group II (bulls with sperm motility $<70 \%$ ). The seminal protein plasma concentration was only used as basic to be analyzed further for electrophoresis or mass spectrometry. The amount of seminal protein plasma concentration cannot be based for judgement as comparison with semen quality (Westfalewicz et al., 2016). However, several studies proved that seminal plasma protein components were considered as effective in affecting better semen quality (Viana et al., 2018; Fu et al., 2019).

Seminal protein plasma concentration has a negative correlation with semen quality parameters such as sperm motility (-0.387), normal sperm morphology (-0.480), sperm concentration (-0.649), and sperm intact acrosome $(-0.157)$ (Table 2). The results revealed that seminal plasma concentration was not correlated with semen quality (Table 1). 
Table 1. Simmental Bulls Fresh Semen Quality and Seminal Plasma Protein Concentration

\begin{tabular}{ccccccc}
\hline & \multicolumn{5}{c}{ Parameters } \\
\cline { 2 - 7 } $\begin{array}{c}\text { Bulls } \\
\text { number }\end{array}$ & $\begin{array}{c}\text { Age } \\
\text { (year) }\end{array}$ & $\begin{array}{c}\text { Sperm } \\
\text { Motility } \\
(\%)\end{array}$ & $\begin{array}{c}\text { Sperm } \\
\text { Concentration } \\
\left(\times 10^{6} \mathrm{~mL}^{-1}\right)\end{array}$ & $\begin{array}{c}\text { Normal Sperm } \\
\text { Morphology } \\
(\%)\end{array}$ & $\begin{array}{c}\text { Sperm Intact } \\
\text { Acrosome }(\%)\end{array}$ & $\begin{array}{c}\text { Seminal } \\
\text { Plasma Protein } \\
\text { Concentration } \\
\left(\mathrm{mg} \mathrm{mL}^{-1}\right)\end{array}$ \\
\hline 61672 & 4 & $70.42 \pm 0.41^{\mathrm{a}}$ & $1203.67 \pm 45.77^{\mathrm{a}}$ & $96.20^{\mathrm{a}}$ & $98.40^{\mathrm{a}}$ & $56.1^{\mathrm{a}}$ \\
61671 & 4 & $70.00 \pm 0.00^{\mathrm{a}}$ & $1551.45 \pm 77.75^{\mathrm{a}}$ & $96.00^{\mathrm{a}}$ & $95.60^{\mathrm{a}}$ & $29.8^{\mathrm{b}}$ \\
61568 & 5 & $70.45 \pm 0.31^{\mathrm{a}}$ & $1609.95 \pm 60.93^{\mathrm{a}}$ & $95.50^{\mathrm{a}}$ & $93.40^{\mathrm{a}}$ & $49.4^{\mathrm{a}}$ \\
61464 & 6 & $70.25 \pm 0.25^{\mathrm{a}}$ & $1575.60 \pm 69.48^{\mathrm{a}}$ & $96.60^{\mathrm{a}}$ & $92.60^{\mathrm{a}}$ & $53.5^{\mathrm{a}}$ \\
61362 & 7 & $70.00 \pm 0.00^{\mathrm{a}}$ & $1251.63 \pm 41.64^{\mathrm{a}}$ & $96.00^{\mathrm{a}}$ & $89.40^{\mathrm{a}}$ & $50.1^{\mathrm{a}}$ \\
61248 & 8 & $70.00 \pm 0.00^{\mathrm{a}}$ & $1769.27 \pm 57.80^{\mathrm{a}}$ & $95.70^{\mathrm{a}}$ & $89.75^{\mathrm{a}}$ & $35.1^{\mathrm{b}}$ \\
61361 & 7 & $64.54 \pm 2.05^{\mathrm{b}}$ & $1657.09 \pm 48.34^{\mathrm{a}}$ & $94.20^{\mathrm{a}}$ & $96.00^{\mathrm{a}}$ & $43.5^{\mathrm{a}}$ \\
61257 & 8 & $50.52 \pm 3.00^{\mathrm{b}}$ & $1252.26 \pm 65.31^{\mathrm{a}}$ & $94.20^{\mathrm{a}}$ & $94.20^{\mathrm{a}}$ & $48.4^{\mathrm{a}}$ \\
61249 & 8 & $60.66 \pm 2.48^{\mathrm{b}}$ & $1032.60 \pm 87.13^{\mathrm{b}}$ & $86.20^{\mathrm{a}}$ & $87.40^{\mathrm{a}}$ & $56.1^{\mathrm{a}}$ \\
\hline \multicolumn{2}{c}{ Means \pm SE } & $64.37 \pm 1.41^{\mathrm{b}}$ & $1403.79 \pm 62.90^{\mathrm{a}}$ & $94.51 \pm 0.30^{\mathrm{a}}$ & $92.97 \pm 1.64^{\mathrm{a}}$ & $46.88 \pm 1.66^{\mathrm{a}}$ \\
\hline
\end{tabular}

Means in a column with different superscripts $\mathrm{a}$ and $\mathrm{b}$ differ significantly at $\mathrm{P}<0.05$

Table 2. Correlation Between Seminal Plasma Protein Concentration and Semen Quality

\begin{tabular}{lc}
\hline \multicolumn{1}{c}{ Parameters } & $\begin{array}{c}\text { Protein } \\
\text { Concentration }\end{array}$ \\
\hline Protein concentration & 1 \\
Sperm motility & $-0.387^{*}$ \\
Normal spermatozoa morphology & $-0.480^{*}$ \\
Sperm concentration & $-0.649^{*}$ \\
Sperm with intact acrosome & $-0.157^{*}$ \\
\hline
\end{tabular}

*Significant correlation $(\mathrm{P}<0.01)$

\section{Protein Profile of Seminal Plasma}

A total of ten protein bands such as $180-156$ $\mathrm{kD}, 134-101 \mathrm{kD}, 100-71 \mathrm{kD}, 70 \mathrm{kD}, 62-48 \mathrm{kD}$, $47-36 \mathrm{kD}, 35 \mathrm{kD}, 34-25 \mathrm{kD}, 20 \mathrm{kD}$ and $15 \mathrm{kD}$ (Table 3) was observed in this study. Analysis result bands $(47-36 \mathrm{kD}, 35 \mathrm{kD}, 20 \mathrm{kD}$ and $15 \mathrm{kD})$ presented in all nine Simmental bulls (100\%), meanwhile other proteins such as $180-156 \mathrm{kD}$ and $34-25 \mathrm{kD}$ were produced only $88.89 \%, 134-101$
$\mathrm{kD} \quad(33.33 \%), \quad 100-71 \mathrm{kD} \quad(55.55 \%), 70 \mathrm{kD}$ (22.22\%), dan 62-48 kD (77.78\%) (Table 3). Six bulls with sperm motility was $>70 \%$ had $8-9$ protein bands, and three bulls with sperm motility $<70 \%$ had 6-7 bands only.

Furthermore, the results showed that protein with MW 134-101 kD, 100-71 kD, $70 \mathrm{kD}$, and 62$48 \mathrm{kD}$ was not found in three bulls with sperm motility $<70 \%$ (Table 3 ). The protein with MW 134-101 kD according to Naaby-Hansen and Herr (2010). contained hypoxia up-regulated 1 (HYOU1). The protein with 100-70 kD MW contained arylsulfatase-a (Odet et al., 2008), heat shock protein 70 (HSP70) in protein $70 \mathrm{kD}$, and $\mathrm{n}$-acetyl-ß3-guicosaminidase in 62-48 kD (Moura et al., 2010).

The absence of proteins such as HYOU1, arylsulfatase A, HSP70, and N-acetyl- $\mathrm{B}$ guicosaminidase in seminal plasma bulls group II (sperm motility was $<70 \%$ ) indicated of low motility sperm in this group (Odet et al., 2008; Naaby-Hansen dan Herr, 2010; Moura et al., 2010). Molecular function mediated sperm motility through A-Kinase Anchoring Protein 4 (AKAP4) setting, then it has correlation with Adenosine triphosphate (ATP) for sperm motility and ATP's dephosphorylation (Freitas et al., 
Table 3. Seminal Plasma Protein Profile of Simmental Bulls Assessed by 1D-SDS-PAGE

\begin{tabular}{rcccccccccc}
\hline & \multicolumn{10}{c}{ MW (kD) } \\
\cline { 2 - 10 } & 61672 & 61671 & 61568 & 61464 & 61362 & 61248 & 61361 & 61257 & 61249 & $\begin{array}{c}\text { Protein } \\
\text { Absence* }\end{array}$ \\
\hline $180-156$ & + & + & + & + & + & - & + & + & + & $8 / 9(88.89)$ \\
$134-101$ & + & - & + & - & - & + & - & - & - & $3 / 9(33.33)$ \\
$100-71$ & + & + & + & + & - & + & - & - & - & $5 / 9(55.55)$ \\
70 & - & - & - & + & + & - & - & - & - & $2 / 9(22.22)$ \\
$62-48$ & + & + & + & + & + & + & + & - & - & $7 / 9(77.78)$ \\
$47-36$ & + & + & + & + & + & + & + & + & + & $9(100)$ \\
35 & + & + & + & + & + & + & + & + & + & $9(100)$ \\
$34-25$ & + & + & + & - & + & + & + & + & + & $8 / 9(88.89)$ \\
20 & + & + & + & + & + & + & + & + & + & $9(100)$ \\
15 & + & + & + & + & + & + & + & + & + & $9(100)$ \\
\hline$\Sigma$ Bands & 9 & 8 & 9 & 8 & 8 & 8 & 7 & 6 & 6 & \\
\hline
\end{tabular}

*n (\%); MW (molecular weight); + (protein expressed); - (protein non-expressed)

2017).

The superior bulls must have high quality semen and high productivity rate for producing frozen semen. Partial assessment cannot be describing as bulls' productivity. To calculate frozen semen production, it must be supported by several data such as semen volume, sperm concentration, and sperm motility. The third multiplier of those data is a total of motile sperm per ejaculate. The total motile sperm per ejaculate divided by insemination dose will be resulted bull straw number or insemination dose per ejaculate.

Total bands for individual were confirmed by straw productivity data. The bulls which shave 89 bands protein with sperm motility $>70 \%$, produced about 265.15 straws per ejaculate, and only 183.74 straws for bulls which have 6-7 bands with sperm motility $<70 \%$. According to SOP of AIC bull semen is collected twice a week for 40 weeks' production in a year, therefore the bulls with 8-9 bands protein yearly will produce about 21212 straws and only 14699.2 straws for bulls with 6-7 bands.

Four protein bands $(47-36 \mathrm{kD}, 35 \mathrm{kD}, 20 \mathrm{kD}$ and $15 \mathrm{kD})$ were presented in all bulls $(100 \%)$ and indicated that they had good fertility. Similar results with several studies reported proteins with MW such as 15-16 kD, 28-30 kD, and 25-15 kD related with high fertility bulls (Kumar et al.,
2013; Druart et al., 2013). Protein with MW 15$30 \mathrm{kD}$ (Druart et al., 2013) indicated as binder sperm protein (BSP) A1/A2, BSP-A3 dan BSP-30 (BSP1, BSP3, and BSP5).

The other protein that almost expressed in all bulls $(88.89 \%)$ were $180-156 \mathrm{kD}$ and $34-25 \mathrm{kD}$ proteins. Based on these proteins MW may be related to fertility such as complement C3 (180 $\mathrm{kD})$ and glutathione peroxidase $3(34 \mathrm{kD})$. C3 protein interacted with apolipoprotein (APOA1) for modulating the sperm membrane and capacitation process (Boe-Hansen et al., 2015). Apolipoprotein is a part of complex high-density lipoprotein (HDL) and it can be interacted with sperm flagella and acrosome protein (Jha et al., 2008). Glutathione peroxidase $3(34 \mathrm{kD})$ is associated with normal sperm morphology (0.664) and sperm intact acrosome (0.564) (Table 3 ).

Table 4 presents the fozen productivity of Simmental Bull. Furthermore, the analysis showed a significant correlation $(\mathrm{P}<0.05$ and $\mathrm{P}<0.01$ ) between protein $\mathrm{MW}$ expression and semen quality parameters (Table 5). The protein with MW 100-71 kD correlated with motility, normal morphology, and sperm concentration. All semen quality parameters were significantly related to protein $62-48 \mathrm{kD}$. Protein expression with $\mathrm{MW}$ is $100-71 \mathrm{kD}$ and $62-48 \mathrm{kD}$ may be related to catalytic activity function. 
Table 4. Frozen Semen Productivity of Simmental Bulls' in Ungaran Artificial Insemination Center

\begin{tabular}{ccccccc}
\hline \multirow{2}{*}{$\begin{array}{c}\text { Bulls } \\
\text { Number }\end{array}$} & $\begin{array}{c}\text { Aged } \\
\text { (year) }\end{array}$ & $\begin{array}{c}\text { Semen } \\
\text { Volume } \\
(\mathrm{ml})\end{array}$ & $\begin{array}{c}\text { Sperm } \\
\text { Motility }(\%)\end{array}$ & $\begin{array}{c}\text { Sperm } \\
\text { Concentration } \\
\left(\times 10^{6} / \mathrm{ml}\right)\end{array}$ & $\begin{array}{c}\text { Total Motile } \\
\text { Sperm/ ejaculate }\end{array}$ & $\begin{array}{c}\text { Total Straw/ } \\
\text { ejaculate }\end{array}$ \\
\hline 61672 & 4 & $6.6 \pm 0.47^{\mathrm{a}}$ & $70.42 \pm 0.41^{\mathrm{a}}$ & $1203.67 \pm 45.77^{\mathrm{a}}$ & $5594.32^{\mathrm{a}}$ & $223.77^{\mathrm{a}}$ \\
61671 & 4 & $5.0 \pm 0.50^{\mathrm{a}}$ & $70.00 \pm 0.00^{\mathrm{a}}$ & $1551.45 \pm 77.75^{\mathrm{a}}$ & $5430.07^{\mathrm{a}}$ & $217.20^{\mathrm{a}}$ \\
61568 & 5 & $6.7 \pm 0.23^{\mathrm{a}}$ & $70.45 \pm 0.31^{\mathrm{a}}$ & $1609.95 \pm 60.93^{\mathrm{a}}$ & $7599.20^{\mathrm{a}}$ & $303.96^{\mathrm{a}}$ \\
61464 & 6 & $5.3 \pm 0.22^{\mathrm{a}}$ & $70.25 \pm 0.25^{\mathrm{a}}$ & $1575.60 \pm 69.48^{\mathrm{a}}$ & $5866.35^{\mathrm{a}}$ & $234.65^{\mathrm{a}}$ \\
61362 & 7 & $8.8 \pm 0.16^{\mathrm{a}}$ & $70.00 \pm 0.00^{\mathrm{a}}$ & $1251.63 \pm 41.64^{\mathrm{a}}$ & $7710.04^{\mathrm{a}}$ & $308.40^{\mathrm{a}}$ \\
61248 & 8 & $5.5 \pm 0.25^{\mathrm{a}}$ & $70.00 \pm 0.00^{\mathrm{a}}$ & $1769.27 \pm 57.80^{\mathrm{a}}$ & $6811.68^{\mathrm{a}}$ & $272.46^{\mathrm{a}}$ \\
\hline Mean \pm SE & $5.6 \pm 0.81$ & $6.3 \pm 0.30^{\mathrm{a}}$ & $70.18 \pm 0.32^{\mathrm{a}}$ & $1493.61 \pm 58.89^{\mathrm{a}}$ & $6629.06 \pm 254.11^{\mathrm{a}}$ & $265.15 \pm 10.12^{\mathrm{a}}$ \\
\hline 61361 & 7 & $5.0 \pm 0.18^{\mathrm{a}}$ & $64.54 \pm 2.05^{\mathrm{b}}$ & $1657.09 \pm 48.34^{\mathrm{a}}$ & $5347.42^{\mathrm{b}}$ & $213.89^{\mathrm{a}}$ \\
61257 & 8 & $6.4 \pm 0.18^{\mathrm{a}}$ & $50.52 \pm 3.00^{\mathrm{b}}$ & $1252.26 \pm 65.31^{\mathrm{a}}$ & $4048.90^{\mathrm{b}}$ & $161.95^{\mathrm{b}}$ \\
61249 & 8 & $7.0 \pm 0.20^{\mathrm{a}}$ & $60.66 \pm 2.48^{\mathrm{b}}$ & $1032.60 \pm 87.13^{\mathrm{b}}$ & $4384.62^{\mathrm{b}}$ & $175.38^{\mathrm{b}}$ \\
\hline Mean \pm SE & $7.6 \pm 0.28$ & $6.1 \pm 0.18^{\mathrm{a}}$ & $55.57 \pm 2.51^{\mathrm{b}}$ & $1313.98 \pm 66.92^{\mathrm{a}}$ & $4593.65 \pm 337.01^{\mathrm{b}}$ & $183.74 \pm 13.48^{\mathrm{b}}$ \\
\hline
\end{tabular}

Means in a column with different superscripts $a$ and $b$ differ significantly at $\mathrm{P}<0.05$

Table 5. Correlation Between Molecular Weight of Seminal Plasma Protein and Sperm Characteristics

\begin{tabular}{rcccc}
\hline Protein MW (kD) & Sperm Motility & $\begin{array}{c}\text { Normal Sperm } \\
\text { Morphology }\end{array}$ & $\begin{array}{c}\text { Sperm } \\
\text { Concentration }\end{array}$ & Intact Acrosome \\
\hline $180-156$ & -0.164 & -0.133 & -0.338 & 0.358 \\
$134-101$ & 0.461 & 0.457 & 0.352 & 0.371 \\
$100-71$ & $0.625^{*}$ & $0.640^{*}$ & $0.557^{*}$ & 0.386 \\
70 & 0.318 & 0.319 & -0.053 & -0.029 \\
$62-48$ & $0.784^{* *}$ & $0.788^{* *}$ & $0.678^{*}$ & $0.502^{*}$ \\
$47-36$ & - & - & - & - \\
35 & - & - & - & - \\
$34-25$ & -0.164 & -0.206 & -0.169 & 0.109 \\
20 & - & - & - & - \\
15 & - & - & - & - \\
\hline
\end{tabular}

**Significant correlation $(\mathrm{P}<0.05)$; *very significant correlation $(\mathrm{P}<0.01)$; - = all proteins $100 \%$ expressed; MW (molecular weight)

The protein with MW 100-71 $\mathrm{kD}$ can be indicated as arylsulfatase-a (protein from bulls' cauda epididymis) (Moura et al., 2010). This protein can be attached to superficial sperm head (Weerachatyanukul et al., 2003). The protein Nacetyl- $\beta$-guicosaminidase $(62-48 \mathrm{kD})$ is a glucose 
hydrolyze enzyme for glycoprotein membrane during sperm maturation in the epididymis (Moura et al., 2010). These proteins are potential mediated sperm-oocyte interactions (Abascal et al., 1998).

Normal sperm morphology had shown a significant correlation $(p<0.05)$ with seminal plasma protein expressed such as MW 100-71 kD (0.640) and 62-48 kD (Table 5). In this study, the range of seminal plasma proteins MW related with normal sperm morphology. These findings indicate that proteins play a role during normal spermatogenesis process. Seminal plasma protein has function in the sperm maturation process on activated protein kinase tract (Fu et al., 2019).

Sperm motility and morphology are important aspects of bulls' fertility or fertilization success determination (Kaya and Memili et al., 2016). Sperm must be alive, motile (progressive movement), normal shape with intact DNA for fertilizing the oocyte (Nagy et al., 2013). Motile sperm not always have a normal shape and good chromatin (Nagy et al., 2013). Comprehensive evaluation for semen quality is important to do for prevention the under quality sperm spread, because it will impact to decreasing the livestock quality and genetic abnormalities (Chenoweth, 2005). Sperm abnormalities rate $18-20 \%$ are considered as serious problem and decreased the fertility rate (Barth and Oko, 1989).

The existing correlation from some molecular protein of seminal plasma in this study can be an additional reference in superior bulls' candidate selection. Hence to optimize the result, protein profiling base on MW is still necessary to investigate fot further confirmation using Liquid Chromatography-mass spectrometry (LCMS/MS) method.

\section{CONCLUSION}

Protein analysis based on MW using SDSPAGE can be used as a semen quality biomarker in Simmental bulls. The semen quality does not always have positive correlation with bulls' reproduction performance; therefore, evaluation the semen quality with molecular basis as an additional indicator beside BSE in the selection process is needed.

\section{ACKNOWLEDGMENTS}

The authors are thankful to DIKTI through Domestic Postgraduate Scholarship (BPPDN) and
Doctoral Dissertation Research Grant (PDD) as financier (Contract No: 1/E1/KP.PTNBH/2020 and 1/AMD/E1.KP.PTNBH/2020, year 2020). Authors are also thankful to Ungaran Artificial Insemination Center for providing semen samples of the study .

\section{REFERENCES}

Badan Standardisasi Nasional (BSN). Semen beku sapi. SNI 4869.1:2017.

Peraturan Menteri Pertanian Republik Indonesia (Permentan). 2016. Penyediaan dan peredaran semen beku ternak ruminansia nomor: $\quad$ 10/Permentan/PK.210/3/2016. Jakarta: Kementan.

Abascal, I., S.R. Skalaban, K.M. Grimm, M. Avilés, J.A. Martínez-Menárguez and M.T. Castells. 1998. Alteration of the isoform composition of plasma-membraneassociated rat sperm a-L-fucosidase during late epididymal maturation: comparative characterization of the acidic and neutral isoforms. Biochem. J. 333:201-207.

Arifiantini, R.I. 2012. Teknik Koleksi dan Evaluasi Semen pada Hewan. Bogor. IPB Press.

Arifiantini, R.I., B. Purwantara and M. Riyadhi. 2010. Occurrence of sperm abnormality of beef cattle at several artificial insemination centers in Indonesia. Anim. Prod. 12(1):4449.

Barth, A.D. and R.J. Oko. 1989. Abnormal morphology of bovine spermatozoa. Iowa: Iowa State University Press

Boe-Hansen, G.B., J.P.A. Rego, J.M. Crisp, A.A. Moura, A.S. Nouwens, Y. Li, B. Venus, B.M. Burns and M.R. McGowan. 2015. Seminal plasma proteins and their relationship with percentage of morphologically normal sperm in 2-year-old Brahman (Bos indicus) bulls. Anim. Reprod. Sci. 162(90):1-11.

Bradford, M.M. 1976. Rapid and sensitive method for quantitation of microgram quantities of protein utilizing principle of protein dye binding. Anal. Biochem. 72(1):248-254.

Chenoweth, P.J., 2005. Genetic sperm defects. Theriogenology. 64(3):457-468.

Chenoweth, P.J., F.M. Hopkins, J.C. Spitzer and R.E. Larsen. 2010. Guidelines for using the bull breeding soundness evaluation form clinical. Theriogenology. 2(1): 43-50.

Druart, X., and S. de Graaf. 2018. Seminal plasma 
proteomes and sperm fertility. J. Anim. Reprod. Sci. 194(4):33-40.

Druart, X., J.P. Rickard, S. Mactier, P.L. Kohnke, C.M. Kershaw-Young, R. Bathgate, Z. Gibb, B. Crossett, G. Tsikis, V. Labas, G. Harichaux, C.G. Grupen and S.P. de Graaf. 2013. Proteomics characterization and cross species comparison of mammalian seminal plasma. Proteomics. 8(91):13-22.

Freitas, M.J., S. Vijayaraghavan and M. Fardilha. 2017. Signaling mechanisms in mammalian sperm motility. Biol. Reprod. 96(1):2-12.

Fu, Q., L. Pan, D. Huang, Z. Wang, Z. Hou and M. Zhang. 2019. Proteomic profiles of buffalo spermatozoa and seminal plasma. Theriogenology. 134(6):74-82.

Hancock, A.S., P.J. Younis, D.S. Beggs, P.D. Mansell, M.A. Stevenson and M.F. Pyman. 2016. An Assessment of dairy herd bulls in southern Australia: 1. Management practices and bull breeding soundness evaluations. J. Dairy Sci. 99(12):9983-9997.

Jha, K.N., I.A. Shumilin, L.C. Digilio, O. Chertihin, H. Zheng, G. Schmitz, P.E. Visconti, C.J. Flickinger, W. Minor and J.C. Herr. 2008. Biochemical and structural characterization of apolipoprotein A-I binding protein, a novel phosphoprotein with a potential role in sperm capacitation. Endocrinology. 149(5):2108-2120.

Jois, P.S., and P. Manjunath. 2010. The N-terminal part of binder of sperm 5 (BSP5), which promotes sperm capacitation in bovine species is intrinsically disordered. Biochem. Biophys. Res. Commun. 394(4):1036-1041.

Juyena, N.S., and C. Stelletta. 2012. Seminal plasma: an essential attribute to spermatozoa. J. Andol. 33(4):536-546.

Karunakaran, M., C. Vivek, Gajare, A. Mandal, M. Mondal, S.K. Das, M.K. Ghosh, Rai and R. Behera. 2019. Electrophoretic of seminal proteins and their correlation with in vitro sperm characters in Black Bengal buck semen. Vet. World. 12(5):621-628.

Kavak, A., N. Lundeheim, M. Aidinik and S. Einarsson. 2004. Sperm morphology in Estonian and tori breed stalions. Act. Vet. Scan. 45(1):11-18.

Kaya, A., and E. Memili. 2016. Sperm macromolecules associated with bull fertility. Anim. Reprod. Sci. 169(1):88-94.

Kumar, P., D. Kumar and I. Singh. 2012. Seminal plasma proteome: promising biomarkers for bull fertility. J. Agric. Res. 1(1):78-86.
Moura, A.A., Souza, C.E., Stanley, B.A., Chapman, D.A, and Killian, G.J. 2010. Proteomics of cauda epididymal fluid from mature Holstein bulls. J Proteomics. 73(10):2006-2020.

Naaby-Hansen, S. and J.C. Herr. 2010. Heat shock proteins on the human sperm surface. J. Reprod. Immunol. 84(1):32-40.

Nagy, S., A. Johannisson, T. Wahlsten, R. Ijäs, M. Andersson and H. Rodriguez-Martinez. 2013. Sperm chromatin structure and sperm morphology: their association with fertility in AI-dairy Ayrshire sires. Theriogenology. 79(8): 1153-1161.

Odet, F., C. Duan, W.D. Willis, E.H. Goulding, A. Kung, E.M. Eddy and E. Goldberg. 2008. Expression of the gene for mouse lactate dehydrogenase $\mathrm{C}$ (Ldhc) is required for male fertility. Biol. Reprod. 79(1):26-34.

Parthipan, S., S. Selvaraju, L. Somashekar, A. Arangasamy, M. Sivaram and J.P. Ravindra. 2017. Spermatozoal transcripts expression levels are predictive of semen quality and conception rate in bulls (Bos taurus). Theriogenology. 98(4):41-49.

Qu, F., X. Ying, W. Guo, Q. Guo, G. Chen, Y. Liu and Z. Ding. 2007. The role of Zn-alpha2 glycoprotein in sperm motility is mediated by changes in cyclic AMP. Reproduction. 134(4):569-576.

Rodriguez-Villamil, P., V. Hoyos-Marulanda, J.A. Martins, A.N. Oliveira, L.H. Aguiar, F.B. Moreno, A.L. Velho, A.C. MonteiroMoreira, R.A. Moreira, I.M. Vasconcelos, M. Bertolini, and A.A. Moura. 2016. Purification of binder of sperm protein 1 (BSP1) and its effects on bovine in vitro embryo development after fertilization with ejaculated and epididymal sperm. Theriogenology. 85(3):540-554.

Samanta, L., R. Parida, T.R. Dias and A. Agarwal. 2018. The enigmatic seminal plasma: a proteomics insight from ejaculation to fertilization. Reprod. Biol. Endocrinol. 16(41):1-11.

Schneider, C.A., W.S. Rasband and K.W. Eliceiri. 2012. NIH Image to ImageJ: 25 years of image analysis. Nat. Methods. 9(7):671-675.

Viana, A.G.A., A.M.A. Martins, A.H. Pontes, W. Fontes, M.S. Castro, C.A.O. Richart, M.V. Sousa, A. Kaya, E. Topper, E. Memili and A.A. Mora. 2018. Proteomic landscape of seminal plasma associated with dairy bull fertility. Sci. Rep. 8(1):16323. 
Weerachatyanukul, W., H. Xu, A. Anupriwan, E. Carmona, M. Wade, L. Hermo, S.M. Silva, P. Rippstein, P. Sobhon, P. Sretarugsa and N. Tanphai-chitr. 2003. Acquisition of arylsulfatase A onto the mouse spermsurface during epididymal transit. Biol. Reprod. 69(4):1183-1192.
Westfalewicz, B., M.A. Dietrich, A. Mostek, A. Partyka, W. Bielas, W. Nizanski and A. Ciereszko. 2016. Analysis of bull (Bos taurus) seminal vesicle fluid proteome in relation to seminal plasma proteome. J. Dairy Sci. 100(3): 2284-2298. 